\title{
"Our one great national malady": Neurasthenia and American Imperial and Masculine Anxiety at the Turn of the Twentieth Century
}

JUNG Yeonsik*

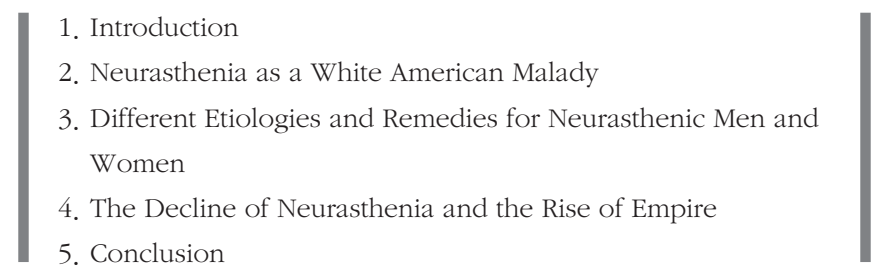

\section{Introduction}

From April 29 to November 11, 1893 the Boston Magnetic Company ran an advertisement for their magnetic pain reliever in The New Nation, a weekly newspaper edited and published by Edward Bellamy, an American journalist and the author of the utopian novel, Looking Backward, 2000-1887.

\footnotetext{
* Associate Professor, Department of English Language and Literature, Sungkyunkwan University / American Literature and Medicine / E-mail: apiaceres@skku. edu
} 
JUNG Yeonsik : "Our one great national malady": Neurasthenia and American Imperial and Masculine Anxiety at the Turn of the Twentieth Century

\begin{abstract}
Wonderful Discovery!! Dr. Ransophier's Electric Magnetic Appliance. An instant relief for all pain. Can be applied to any part of the person easily; never gets out of order. Stops headache in 2 minutes, relieves nervousness and produces sleep, stops neuralgic pains; relieves Rheumatism. Heart troubles, Sciatica, Kidney, Bladder and Liver ailments, can be helped or cured by this Magnetic appliance. Quickens blood, renews Vigor far more effectively than any medecine [sic] to be taken internally; indorsed [sic] by eminent physicians. ${ }^{1)}$
\end{abstract}

Fig. 1. Advertisement for Dr. Ransophier's Electric Magnetic Appliance (1893)

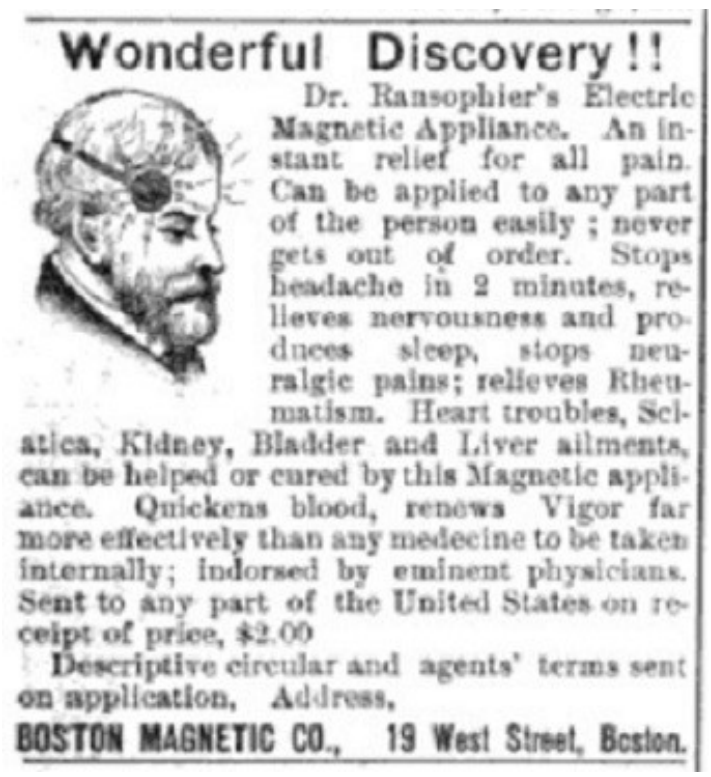

Dr. Ransophier's Electric Magnetic Appliance, a portable medical device, was designed to restore equilibrium to the supply of the cosmic

1) “Dr. Ransophier's Electric Magnetic Appliance," The New Nation, 29 April - 18 November 1893. 
JUNG Yeonsik : "Our one great national malady": Neurasthenia and American Imperial and Masculine Anxiety at the Turn of the Twentieth Century

essence called animal magnetism, an invisible energy or fluid evenly distributed throughout the healthy human body. It was a high-end model through which the patient could practice a sort of mesmerism by himself or herself without being mesmerized, so that the editor of The Western Druggist, inviting the attention of the readers, mostly retail pharmacists, to the advertisement for this device printed also in its page, announced that the Boston Magnetic Company has "a specialty which is worthy your investigation." ${ }^{2)}$

Mesmerism, developed by German physician Franz Anton Mesmer and further by his disciple Marquis de Puységur, who endowed it with a scientific significance in the 1770 s, billed itself as a way to experience a deeper state of consciousness and a truly effective mode of healing. In the wake of the Second Great Awakening which reached its peak about 1830, mesmerism entered American cultural thought and quickly gathered immense popularity, appealing particularly to religious leaders who needed a feat of physic power in their competition for converts, in contrast to the European fascination with it as a passing fad of an idle upper class (Fuller, 1982: 1-15). American fascination with mesmerism was one of the symptoms of rapid social change brought by urbanization, industrialization, and scientific discoveries, which deprived people of their belief in individual independence and a unified perspective toward the world. Individuals were no longer able to directly control their material destinies. A simple philosophy of individualism based on the Protestant work ethic became a poor orientation to a new industrial society that failed to insure a correspondence between individual sincerity and

2) “Dr. Ransophier's Electric Magnetic Appliance,” The Western Druggist, June 1893. 
JUNG Yeonsik : "Our one great national malady": Neurasthenia and American Imperial and Masculine Anxiety at the Turn of the Twentieth Century

social reward. Religion lost much of its suasive power as, by the 1860s, Protestant churches and their revivalism, the product of a rural, middle class society, lacked the social resources to effectively carry out their role in neighborhoods composed of distinct ethnic or economic groups. Addressing newly emerging intellectual and emotional demand for a new and more satisfying worldview, mesmerism attracted a wide assortment of religious sects and utopian social movements, such as spiritualism, theosophism, Christian Scientism, and New Thought movements, which needed a cure for anxious American souls. Intrigued by the era's strong public interest in mesmerism, some religious leaders claimed to be prophets who could bring people to spiritual and physical salvation by cultivating their psychic powers residing in the "god-self" within.

Not surprisingly, American professional medicine in this period, waging a campaign against esoteric and ecstatic therapeutic practices, made efforts to interpret the era's widespread discontent as the symptoms of a neurological disease with psychosomatic origins and cure it without a more costly guidance of a religious prophet. Pathological approach to the age's anxiety yielded a diagnosis of a newly discovered, or invented, mental illness called "neurasthenia," with which latenineteenth-century Anglo-Saxon Americans were entrenched in a battle. In his speech before the New York Medical Journal Association in 1869, iconic American neurologist George M. Beard used the term "neurasthenia," taking American physician Fordyce Barker's "nervous asthenia," to characterize a wide range of neurologic symptoms from simple stress to severe neuroses caused by "deficiency or lack of nerveforce," as clearly suggested by its alternative name, "nervous exhaustion" and "nervous prostration" (Beard, 1881: vi). In fact, diverse symptoms 
JUNG Yeonsik : "Our one great national malady": Neurasthenia and American Imperial and Masculine Anxiety at the Turn of the Twentieth Century

that Dr. Ransophier's Electric Magnetic Appliance proclaimed to cure were the supposed symptoms of this preeminently American ailment of the age, and its inventor Dr. Ransophier presumably shared a belief in electrotherapy with Beard who proposed the application of electricity to the patient's body for treating neurasthenia (Beard, 1867; Caplan, 1998: 52-54).

Beard's contention that neurasthenia was a product of the late nineteenth-century American modernity invited historiographical attention for decades to the ways in which its medical discourse manifested the age's ideological evaluation of vice and virtue which was instrumental in shaping and sustaining the political and cultural order of fin-de-siècle America. Focusing on educated white upper-middle-class American men's alleged vulnerability to neurasthenia, scholars investigated how turn-ofthe-twentieth-century American doctors and patients linked whiteness with weakness and, in turn, considered neurasthenia as a racial asset that paradoxically attested to white supremacy (Rosenberg, 1962: 245-259; 1997: 98-108; Haller \& Haller, 1977: 5-43; Gosling, 1987; Carter, 2007: 4274). Feminist critics and historians utilized male physicians' misogynist portraits of nervous women as a lens through which to view Victorian patriarchal culture and analyze the crisis of American masculinity that enabled them to invent the medical discourse of neurasthenia (Wood, 1973: 25-52; Smith-Rosenberg, 1986: 197-216; Showalter, 1987: 101144). Although much ink has been spilled over the rise and popularity of neurasthenia and its cultural significance in the 1880s-1910s, scant attention was paid to the decline of neurasthenia as a valid diagnostic category around the 1920s. Despite their skepticism about setting of dates for the life-span of mental diseases like neurasthenia, scholars like Brad 
JUNG Yeonsik : "Our one great national malady": Neurasthenia and American Imperial and Masculine Anxiety at the Turn of the Twentieth Century

Campbell and David G. Schuster recently wrote a history of its decline (Campbell, 2007: 157-178; Schuster, 2011: 140-158). They attributed the cause of the decline, however, mostly to the transformation of American medicine such as the emergence of psychiatric knowledge that rendered the neurasthenia diagnosis obsolete and, in turn, did not consider enough that neurasthenia was a cultural as well as medical construction that represented the prevailing political ideology and collective anxiety of the period.

Examining the ways in which neurasthenia was invented as a white American malady and refigured as a white male malady, respectively, in the second and third chapters, this essay seeks to claim that the decision to move away from the neurasthenic diagnosis was rather a cultural phenomenon, which reflected the American ascendancy to global power in the early twentieth century, particularly after the First World War. Given that one of the remedies for neurasthenic men was a retreat to nature or wilderness, neurasthenia was a disease tied to late nineteenth-century American's spatial anxiety about the diminishing frontier epitomized by Frederick Jackson Turner's thesis of “end of the frontier." Exploring the ways in which the medical discourse of neurasthenia addressed late nineteenth-century American men's anxiety not only about the racial and sexual heterogeneity but also about the decline of the American pastoral ideal caused by the closure of the frontier, this essay will investigate the racial, sexual, and imperial framing of neurasthenia that envisioned empire as the site for rejuvenating American identity and masculinity. 
JUNG Yeonsik : "Our one great national malady": Neurasthenia and American Imperial and Masculine Anxiety at the Turn of the Twentieth Century

\section{Neurasthenia as a White American Malady}

It was not George Beard who first coined the term "neurasthenia." Prior to Beard, it had been used by Gianini, a professor in Milan, in 1808 and in the 1883 volume of Robley Dunglison's Dictionary of Medical Science "side by side with its German equivalent, Nervenschwache" (Gosling, 1987: 26). In 1869, the very year that Beard had announced his discovery of neurasthenia, Edwin H. Van Deusen, an alienist (the nineteenth-century title for a psychiatrist) and superintendent of the Michigan Asylum for the Insane at Kalamazoo, also provided a description of neurasthenia as "a distinct form of disease" caused by "excessive mental labor, especially when conjoined with anxiety and deficient nourishment" in his article, "Observations on a Form of Nervous Prostration, (Neurasthenia,) Culminating in Insanity" (Van Deusen, 1869: 445). Van Deusen singled out isolation and loneliness as the catalyst for neurasthenia, identifying young wives in "an isolated farm-house" who led a monotonous household life lacking "a requisite measure of social and intellectual recreation" as particularly prone to this new disease (Van Deusen, 1869: 447).

It was Beard, however, who first described "neurasthenia" as a clinical entity more consistently and scientifically than anyone before and more correspondingly to the era's widespread feeling of uneasiness and restlessness in his essay "Neurasthenia, or Nervous Exhaustion" (1869) published in the Boston Medical and Surgical Journal and in three ensuing, somewhat redundant books, A Practical Treatise on Nervous Exhaustion (Neurasthenia) (1880), American Nervousness: Its Causes and Consequences (1881), and Sexual Neurasthenia (Nervous 
JUNG Yeonsik : "Our one great national malady": Neurasthenia and American Imperial and Masculine Anxiety at the Turn of the Twentieth Century

Exhaustion) (1884). Like the disciples of mesmerism, Beard regarded "civilization" as "the one constant factor without which there can be little or no nervousness, and under which in its modern form nervousness in its many varieties must arise inevitably" (Beard, 1881: vi). He claimed that the complex stimulations of modern civilization "represented by steam-power, the periodical press, the telegraph, the sciences" which increased the tempo of both business and daily life squandered urban Americans' finite supply of nervous force and thus forced them to suffer from neurasthenia (Beard, 1881: vi). While Van Deusen's diagnosis that directly links "between neurasthenia and insanity" made patients and physicians alike shy away from it, Beard's neurasthenia diagnosis rested on conceptual connection with modern civilization appealed to potential patients in the city (Schuster, 2011: 15).

The pathology and etiology of neurasthenia, however, had not strictly been defined as revealed in Beard's fanciful two-page list of neurasthenic symptoms which includes apparently unrelated ones such as dyspepsia, headache, near-sightedness, chorea, asthenopia, hay-fever, and hypochondria. Seeking to express the patients' bodily weakness and exceptional vulnerability to a barrage of sensory stimuli, the list even contains what appears not to be pathological: fear of lightning, or fear of responsibility, of open spaces or of closed places, fear of society, fear of being alone, fear of fears,

fear of contamination, fear of everything, deficient mental control, lack of decision in trifling matters, hopelessness, deficient thirst and capacity for assimilating fluids, abnormalities of the secretions, salivation, tenderness of the spine, and of the whole body, sensitiveness to cold or hot water, sensitiveness 
JUNG Yeonsik : “Our one great national malady": Neurasthenia and American Imperial and Masculine Anxiety at the Turn of the Twentieth Century

to changes in the weather, coccyodynia $\cdots$ exhaustion after defecation and urination, dryness of the hair, falling away of the hair and beard, slow reaction of the skin, etc. (Beard, 1881:

7-8)

Beard ended this long list by noting that " $[\mathrm{t}]$ he above list is not supposed to be complete, but only representative and typical," and this simply indicates the fictitious nature of neurasthenia (Beard, 1881: 8).

Even more interestingly, Beard considered the "fine organization" characterized "by fine, soft hair, delicate skin, nicely chiseled features, small bones, tapering extremities, and frequently by a muscular system comparatively small and feeble" as physiological evidence of people who were prone to neurasthenia (Beard, 1881: 26). According to the American neurologist,

It[fine organization] is frequently associated with superior intellect, and with a strong and active emotional nature. ${ }^{\cdots}$ It is the organization of the civilized, refined, and educated, rather than of the barbarous and low-born and untrained-of women more than of men. It is developed, fostered, and perpetuated with the progress of civilization, with the advance of culture and refinement, and the corresponding preponderance of labor of the brain over that of the muscles. (Beard, 1881: 26)

That is, neurasthenia was a sort of hereditary racial disease that struck only Anglo-Saxon American men and women, particularly members of the leisure class and "brain-workers," who expended their nerve energy in professional and intellectual work and, in turn, could not cope with the huge amount of stimuli brought on by urban-industrial modernity. 
JUNG Yeonsik : "Our one great national malady": Neurasthenia and American Imperial and Masculine Anxiety at the Turn of the Twentieth Century

It means that non-whites, regardless of class and sex, were not regarded as possible objects of this "American nervousness." Neurasthenia "scarcely exists among savages or barbarians, or semi-barbarians or partially civilized people," that is, immigrants and African-American whose brains were claimed not to be developed enough to feel the exhaustion of emotional and mental resources (Beard, 1881: 92). In addition, white lower-class workers with "very strong, old-fashioned constitutions" were also considered to be naturally immune to the deleterious effects of civilization and therefore to neurasthenia (Beard, 1884: 259): "in the lower orders in our great cities, and among the peasantry in the rural districts, muscle-workers, as distinguished from brain-workers, ‥ functional nervous diseases, except those of a malarial or syphilitic character, are about as rare as they were among all classes" (Beard, 1881: 92). This explains in part why Boston Magnetic Company placed the advertisement for Dr. Ransophier's Electric Magnetic Appliance in Bellamy's The New Nation, a newspaper subscribed to mostly by white, native-born, educated middle-class Americans.

Late nineteenth-century American physicians, particularly neurologists who specialized in the treatment of mental disorders, held a belief that "mental states were merely concomitants of physical states" and therefore interpreted "psychical symptoms as signs of some underlying but not yet discernible physical lesion" (Caplan, 1998: 3). Despite the lack of physical proofs, however, "by the early 1880s neurasthenia's status as a distinct disease entity, while not universally embraced, received little challenge" (Caplan, 1998: 38). Even after Robert Koch and Louis Pasteur discovered pathogenic bacteria such as bacillus anthracis and tubercle bacillus and changed the way people regarded infection, replacing the miasma theory 
JUNG Yeonsik : "Our one great national malady": Neurasthenia and American Imperial and Masculine Anxiety at the Turn of the Twentieth Century

of disease with the germ theory in the 1870s-80s, no "microscopic and chemical examination" about neurasthenia was demanded. Suffice it to say, as J. S. Green maintained in his 1883 essay, that "[t]he influences which lead to nervous exhaustion are all-pervasive. They permeate the atmosphere of our modern civilization as bacteria do the air we breathe" (Green, 1883: 76).

Beard's theory swept through Europe as well. The symptoms pertaining to neurasthenia were labeled commonly as those of neurosis in Europe (Showalter, 1985: 134-137), and the social etiology of neurasthenia was criticized by several prominent French psychiatrists like Bénédict Augustin Morel and Jean-Martin Charcot who insisted on the hereditary etiology of nervous disorders. Yet the majority of physicians in Europe welcomed it. ${ }^{3)}$ For example, a Paris physician Achille-Adrien Proust who coauthored the standard textbook on neurasthenia in the fin-desiècle France, L'hygiène du neurasthénique, (and fathered the author of A la recherche du temps perdu) supported Beard's characterization of neurasthenia as a disease for "civilized peoples, in whom the struggle for existence keeps up an incessant and exaggerated exaltation of the functions of the nervous system" (Proust and Ballet, 1902: 7). He also agreed to the definition of neurasthenia as an "American nervousness," recognizing the extreme frequency of neurasthenia "among Americans, whose extraordinary activity is well known" (Proust and Ballet, 1902: 7).

Late nineteenth-century Americans' exceptional vulnerability to neurasthenia was alleged to be aggravated from their struggle for

3) For the European medical professionals' response to Beard's theory of neurasthenia, see Marijke Gijswijt-Hofstra and Roy Porter, eds., Cultures of Neurasthenia: From Beard to the First World War (Amsterdam: Rodopi, 2001); Anson Rabinbach. The Eclipse of the Utopias of Labor (New York: Fordham University Press, 2018), 91-99. 
JUNG Yeonsik : "Our one great national malady": Neurasthenia and American Imperial and Masculine Anxiety at the Turn of the Twentieth Century

existence against the "new" immigrants, which thrusted American culture onto untested ground lacking in social homogeneity. The thirty years immediately following the Civil War saw almost every urban center in the Northeast America triple in size, and the "new" immigrants from southern and eastern Europe who headed straight for the city in the 1880s-90s further transformed the city into a grab bag of divergent people. Unlike the "old" immigrants from the British Isles, German, and northern Europe from 1820s to 1870 s, the Protestants who were easily assimilated into mainstream American society, the "new" immigrants from "less" Nordic nations were believed to be aliens ineligible to be American citizens because of their heterogeneous language, religions, and customs. Seen as the imminent threat to autonomous "American" selfhood, these "new" immigrants reignited Anglo-Saxon nativism that continued to grow by early twentieth century (Higham, 1955: 158-175).

Moreover, "new" immigrants' poverty-stricken, intemperate, and unhygienic lifestyle and, in the case of Asian immigrants, ignorance of Western medicine shaped Anglo-Saxon nativism in this period into what Alan Kraut describes as a "medicalized nativism" that stigmatized certain immigrants as potential carriers and distributors of pathogenic germs (Kraut, 1994: 3). Communicable disease epidemics bred by the squalor of tenements were associated with particular immigrant groups. For example, the Irish in New York were wrongly blamed for the cholera epidemic of 1832, and the outbreaks of smallpox in the 1860s, 1870s, and 1880s and of a bubonic plague in the 1900s produced anti-Chinese bias. The 1892 typhus and cholera quarantines justified anti-Semitism, inequitably targeted Eastern European Jews, and the 1916 polio epidemic was, similarly, believed to have originated from Italians (Wald, 2008: 115; 
JUNG Yeonsik : "Our one great national malady": Neurasthenia and American Imperial and Masculine Anxiety at the Turn of the Twentieth Century

Humphrey, 2002: 852). In addition, American eugenicists of the early twentieth century condemned these immigrants as racial degenerates who threatened the racial health of the nation. Warning of the danger of unregulated immigration, Charles B. Davenport, the father of the discipline, argued in his 1911 book that "the population of the United States will, on the account of the great influx of blood from South-eastern Europe, rapidly become darker in pigmentation, smaller in stature, more mercurial, $\cdots$ more given to crimes of larceny, kidnapping, assault, murder, rape and sex-immorality" (Davenport, 1911: 219).

Due to their alleged racial, mental, and moral deficiency, as noted above, "new" immigrants were assumed to be immune to neurasthenia. At the same time, constituting an essential part of the urban modernity that assailed late-nineteenth-century native-stock Americans' senses, (imagined) threats from heterogeneous immigrants were believed to give rise to the symptoms of neurasthenia, albeit no clear physical cause was provided. Neurasthenia was indeed a neurological expression of late nineteenth-century American medicalized nativism, which, functioning as "a window into the Gilded Age construction of whiteness as weakness," paradoxically supported "white bourgeois claims to legitimate ownership and dominance of American culture" (Carter, 2007: 43-44).

\section{Different Etiologies and Remedies for Neurasthenic Men and Women}

In his first 1869 speech about neurasthenia Beard was convinced that proof of his diagnosis would "in time be substantially confirmed by microscopic and chemical examination of those patients who die 
JUNG Yeonsik : "Our one great national malady": Neurasthenia and American Imperial and Masculine Anxiety at the Turn of the Twentieth Century

in a neurasthenic condition" (Beard, 1869: 218). Yet his later works on neurasthenia including the magnum opus, American Nervousness: Its Causes and Consequences, did not provide any results of "microscopic and chemical examination." Indeed the medical discourse of neurasthenia was filled with excessive use of metaphor, which did little to define it as a clinical entity. Nevertheless, neurasthenia made it a popular way of understanding personal health in late nineteenth-century America because its class-, race-, and gender-conscious diagnosis, which transformed white American men's bodily weakness into compelling evidence of their racial and sexual superiority, appealed to both male doctors and male patients. We know that a claim to superiority often attests to anxiety about one's precarious status. Along with great waves of seemingly unassimilable immigrants, a historical and cultural phenomenon that occurred concurrently in the late nineteenth century United States invoked a collective anxiety over sexual as well as racial others encroaching on American life, calling forth an imminent need for Anglo-Saxon American men to reaffirm the racist and misogynist value systems of a society that was under threat: women's claim for professional independence and sexual freedom.

Beard speculated that neurasthenia was "found in great abundance in both sexes, and in both men and women of intellect, education, and wellbalanced mental organizations" (Beard, 1880: 137). Indeed, for example, prominent neurologist Smith Ely Jelliffe reported 364 neurasthenic patients he treated in 1903, of which 211 were men and 152 women (Jelliffe, 1904: 314). The two sexes' disease, however, was believed to be etiologically different and thus yielded different remedies. Neurasthenic symptoms were associated with feminine traits. Hence "for some men neurasthenia 
JUNG Yeonsik : "Our one great national malady": Neurasthenia and American Imperial and Masculine Anxiety at the Turn of the Twentieth Century

served as evidence that they failed in their duties as husbands and fathers and no longer possessed the powerful 'will"' that defined manly character (Schuster, 2011: 86). Given that Beard looked upon "the mental activity of women" as one of the characteristics of modern civilization, American men's neurasthenia was no other than their anxiety about the loss of white male dominance and privilege, which was, in fact, aligned with their fear of unruly white women (Beard, 1881: vi).

Most busy neurasthenic men were often treated with electrotherapy. With a portable instrument like Dr. Ransophier's Electric Magnetic Appliance they could treat themselves at home easily and relatively inexpensively. Some well-to-do patients afforded costly rest cure which commonly consisted of bed rest, massage, a diet of restorative foods, as well as electrotherapy. Yet a retreat to nature and wilderness, to a place where patients could restore their exhausted nerve force and build a strong, masculine body was recommended by Beard and other physicians as an ideal treatment for effeminate neurasthenic men. For example, Theodore Roosevelt took a trip to South Dakota to cure his asthma and other neurasthenic symptoms in the early 1880s. Before his retreat to the West, people lampooned Roosevelt as "the quintessence of effeminacy," calling him "weakling," "Jane-Dandy," "Punkin-Lily," and "the exquisite Mr. Roosevelt" (Bederman, 1995: 170). But during this therapeutic retreat, Roosevelt succeeded to masculinize his image as well as restore his health and, returning to East, "soon came to embody powerful American manhood” (Bederman, 1995: 170). He ran for mayor of New York as the "Cowboy of the Dakotas," became known as Colonel Roosevelt who led the Rough Rider in Cuba, and then served as the twenty-sixth president of the United States, being remembered as the 
JUNG Yeonsik : "Our one great national malady": Neurasthenia and American Imperial and Masculine Anxiety at the Turn of the Twentieth Century

advocate for the strenuous life and the quintessential symbol of turn-ofthe-twentieth-century American masculinity.

On the other hand, women become neurasthenics "when they tried to combine their normal function-motherhood-with the masculine, enervating intellectual demands of modern civilization" (Bederman, 1995: 130). In the theory of neurasthenia rooted in the Victorian gender ideology, (white) woman was defined as the sex with limited nerveforce and intellectual labors were believed to drain it rapidly and, in turn, bring out neurasthenic symptoms. While industrial development in the mid to late nineteenth century, separating work from residence, thrust men out into the world of business, women were not allowed to leave kitchen and nursery where they were carrying out their (re)productive work of pregnancy, childbirth, and childrearing. Spending less and less time in domestic labor, however, many upper middle-class American girls became ill-prepared to assume the responsibilities of marriage and motherhood and resisted walking in their mothers' footsteps into the Ideal Mother, a strong, self-reliant, and efficient caretaker of the home. Since the 1880s, as a consequence, the New Women, daughters and granddaughters of American Victorian women in the home, or at best in women's clubs like YWCA (Young Women's Christian Association), and the WCTU (Woman's Christian Temperance Union), entered the stage of American life, making a claim for gender equality. For latenineteenth-century traditional-minded men, these New Women educated at the newly built women's college were no other than the symbol of social disorder and sexual transgression (Matthews, 2003: 3-35; SmithRosenberg, 1986: 32-47).

Medical discourses about the neurasthenic woman reiterated those 
JUNG Yeonsik : "Our one great national malady": Neurasthenia and American Imperial and Masculine Anxiety at the Turn of the Twentieth Century

about hysteric women except that hysteria, unlike neurasthenia, was diagnosed as a disease alleged to affect only women, not only those who were aspiring to professional independence and sexual freedom, but also "the stout Irish servant girls, $\cdots$ the Southern negroes, and $\cdots$ the undisciplined and weak-minded of all races and classes and ages" (Beard, 1880: 137). In fact, hysteria held "the most significant position in the ideology and practice of nineteenth-century European psychiatry as an equivalent to nervous disorder" before neurasthenia (Jung, 2017: 436). This explains why Michel Foucault, in the first volume of The History of Sexuality, proposed a hysterization of women's bodies, along with a pedagogization of children's sex, a socialization of procreative behavior, and a psychiatrization of perverse pleasure as the "great strategic unities which, beginning in the eighteenth century, formed specific mechanisms of knowledge and power centering on sex" (Foucault, 1990: 103). Crystallizing the cultural values and gender relationships of a Victorian patriarchal culture anxious about its rebellious daughters, hysteria functioned as a pathologic sign of women's emotional sensitivity and instability, limited intellectual capacity, and unregulated sexual desire (Micale, 1995: 21-25; Showalter, 1987: 145-164). It was less a mental disease than a convenient diagnostic box for threatening an educated, unconventional women to observe the norms of feminine conduct.

No wonder medical treatment of hysteria in women was rather a punishment. Based on the classical understanding of hysteria as "wandering womb" that linked all female diseases to the vagaries of their reproductive system, male physicians cauterized hysteric woman's clitoris and performed ovariotomies. In her short story, "The Yellow Wall-paper," Charlotte Perkins Gilman described the widespread use of 
JUNG Yeonsik : "Our one great national malady": Neurasthenia and American Imperial and Masculine Anxiety at the Turn of the Twentieth Century

the rest cure, a more humane treatment invented by S. Weir Mitchell, as a remedy for hysteria in late nineteenth century America and its inefficiency and cruelty. ${ }^{4)}$ The rest cure for neurasthenic men was a luxury. The rest cure for woman, which confined her to the bed, flat on her back and permitted neither to read nor to rise to urinate for weeks, however, was "a punishment and an agent of regeneration" that aimed to symbolically replicate the conditions of pregnancy, the visible emblem of masculine potency and feminine submissiveness (Wood, 1973: 37). Not surprisingly, Mitchell called a hysterical woman, to quote Oliver Wendell Holmes's words, "a vampire who sucks the blood of the healthy people about her" (Mitchell, 1884: 49).

Yet significant numbers of American upper middle-class male nerve patients who seemed to suffer from hysteric symptoms such as "paroxysms, an acuteness, violence, activity, and severity that do not belong to simple neurasthenia" (Beard, 1880: 137) brought forth a need for "an acceptable, even impressive illness for white men, because these patients must not be diagnosed as suffering from hysteria, 'the daughter's disease" (Jung, 2017: 436). Also the existence of colored women reported to suffer from neurasthenic symptoms further urged American medical and psychological wisdom to revise Beard's theory of neurasthenia in order to make it a purely white male malady. Indeed nervous women were more often diagnosed with hysteria and nervous men exclusively with neurasthenia in the 1890s-1900s.

4) For the cases of educated neurasthenic women including Charlotte Perkins Gilman, Amelia Gere Mason, Sarah Butler Wister, and Edith Wharton, see Tom Lutz, American Nervousness, 1903 (Ithaca, NY: Cornell University Press, 1991), 221-243; David G. Schuster, Neurasthenic Nation (New Brunswick, NJ: Rutgers University Press, 2011), 95-112. 
JUNG Yeonsik : “Our one great national malady": Neurasthenia and American Imperial and Masculine Anxiety at the Turn of the Twentieth Century

Since neurasthenia and hysteria shared similar etiology and symptoms, however, "it is not always possible," according to late nineteenthcentury American physician and neurologist Morton Prince, "to draw a sharp line of distinction between" the two diseases (Prince, 1898: 652). American physicians' struggle to differentiate the two similar diseases, in this sense, demonstrates that neurasthenia was a class-, race-, and gender-related cultural phenomenon in the turn of the twentieth century United States. The idea of neurasthenia as white American (wo)men's malady functioned as a mark both of whites' racial superiority to "new" immigrants and African Americans and of women's intellectual inferiority to the opposite sex of their own race. Imposing a subtle distortion on the etiology and diagnosis of neurasthenia and associating it with specific groups of people, the "American disease" constituted the era's representative pathological symptoms which addressed Anglo-Saxon American men's anxieties about overcivilized effeminacy and racial and national decadence which was originated as a response to the racial and sexual heterogeneity.

\section{The Decline of Neurasthenia and the Rise of Empire}

The neurasthenic diagnosis which reached its peak in the 1880s-90s rapidly lost its medical and cultural significance around 1920. Early twentieth-century American physicians like Robert S. Carroll, Wade Wright, and Peter Bassoe sensed the decline of neurasthenia as a disease with a clinical validity at that time, and most medical historians have concurred with this view (Carroll, 1917: 23; Wright, 1921: 497; Bassoe, 
JUNG Yeonsik : "Our one great national malady": Neurasthenia and American Imperial and Masculine Anxiety at the Turn of the Twentieth Century

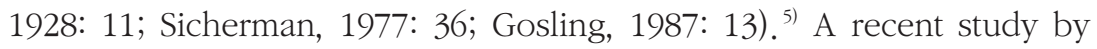
David G. Schuster verified this claim about the lifespan of neurasthenia by counting the number of reference to this disease in the New York Times from 1890 to 1949; the term "neurasthenia” (including its cognates, "nervous prostration" and "nervous exhaustion") which was mentioned 875 times from 1890 to 1899 was found only 248 times from 1920 to 1929, while the number of reference to the terms like "nervous breakdown," "psychosis," and "neurosis" increased from 33 times to 1071 times during the same period (Schuster, 2011: 162-163).

The continued efforts to professionalize American medicine at the turn of the century represented by the establishment of Johns Hopkins Medical School in 1893, the re-organization of the American Medical Association in 1901, and the publication of the Carnegie Foundation's Flexner Report in 1910 which reformed and standardized medical education and health care were responsible for the decline of neurasthenia. ${ }^{6}$ For a new generation of American physicians who sought to transform medicine into a scientific discipline and not to share medical authority over symptoms with quack

5) It should be noted that the term, "neurasthenia," flourished in the 1950s-60s and revived in the 1970s-80s in non-Western cultures, especially in China. Also, some considered the rise of chronic fatigue syndrome in the 1980s as the signs of the revival of neurasthenia also in Western cultures (Kleinman, 1986: 152-156; Lee, 1999; 349-380; Wang, 2019: 443-456; Wessely, 1990: 35-53; Ware and Kleinman, 1992: 546-560). It is beyond the scope of this essay, however, to map out the transformation and revival of neurasthenia outside the turn-of-the-twenty-century American context.

6) For the conflict and convergence of the American medical professions in the late nineteenth century that led to the (re)formation of the American Medical Association, see Paul Starr, The Social Transformation of American Medicine (New York: Basic Books, 1982), 90-119. For the Flexner Report which recommended medical schools to provide "a more uniformly arduous and expensive medical education" (Flexner, 1910: 13) and its effect on the reorganization of American medical education in 1910s-20s, see Andrew H. Beck, "The Flexner Report and the Standardization of American Medical Education" Journal of American Medical Association 291.17 (2004): 2139-2140. 
JUNG Yeonsik : "Our one great national malady": Neurasthenia and American Imperial and Masculine Anxiety at the Turn of the Twentieth Century

doctors, patients, and pharmacy advertisers, Beard's unproven theory of nervous energy was no longer acceptable. Recent discoveries of chemical factors like hormones and vitamins offered them with a more specific theory of health built on clinical laboratory science such as endocrinology and dietetics. ${ }^{7}$ More importantly, the rise of psychiatry and psychology which put more emphasis on psychic factors than somatic ones in the understanding of pain and discomfort reconceptualized the neurasthenic symptoms as the result of mental disorders (Schuster, 2011: 141-142). ${ }^{8}$ Indeed "a kind of intellectual renaissance in psychiatry which has aroused deeply the interest and respect of neurologists" made early twentiethcentury American physicians cast serious doubt on the validity of the neurasthenic diagnosis, as Charles L. Dana claimed, slightly prematurely, in his 1904 speech, "The Partial Passing of Neurasthenia," that,

a large number of these so-called neurasthenias and all the hysterias should be classed as prodromal stages, abortive types or shadowy imitations of the great psychoses. For in these cases it is the morbid mind that dominates the situation, not a weak eye-muscle, a poor stomach, a heavy womb, uric

7) For the discovery of hormone and the founding of endocrinology, and their impact on the psychiatric understanding of mental disease in the 1910s-30s, see Amy Koerber, From Hysteria to Hormones (University Park, PA: The Pennsylvania State University Press, 2018). For the case of vitamins in this period, see Kenneth J. Carpenter, The History of Scurvy and Vitamin C (Cambridge: Cambridge University Press, 1988); Louis Rosenfeld, "Vitamine-vitamin. The Early Years of Discovery" Clinical Chemistry 43.4 (1997): 680-685; Rima D. Apple, Vitamania: Vitamins in American Culture (New Brunswick, N. J.: Rutgers University Press. 1996).

8) See Eric Caplan, Mind Games: American Culture and the Birth of Psychotheraphy (Berkeley: University of California Press, 1998); Laura D. Hirshbein, American Melancholy: Constructions of Depression in the Twentieth Century (New Brunswick, NJ: Rutgers University Press, 2009), 95-112, for the birth of psychotheraphy in early twentieth-century American medicine and the ways in which American psychiatrists and neurologists developed a clinical theory about diverse mental diseases. 
JUNG Yeonsik : "Our one great national malady": Neurasthenia and American Imperial and Masculine Anxiety at the Turn of the Twentieth Century

acid, arterial sclerosis or even an exhausted motor, nerve cell. (Dana, 1904: 339)

Most physicians and neurologists in the 1920s therefore agreed that neurasthenia was "a description of a complex of symptoms that might indicate a number of different disease," if not, "simply a cover for ignorance" (Lutz, 2001: 59-61).

It should be noted that as late as the 1930s, however, neurasthenia was still a heated topic for medical discussion among non-professional physicians and lay people, frequently mentioned in pseudo-medical treatises, selfhelp books, novels, and memoirs, mostly due to its commercial value for marketing patent medicine (Campbell, 2007: 158-159). There was even a claim that neurasthenia seemed to have disappeared just because the patients "could no longer afford the luxury of neurasthenia": that is, due to the economic crisis, mass unemployment, and hyperinflation that struck the U.S. in the 1920s-30s, they "had neither the time nor the money for treatment” (Kury, 2017: 60-61). Even by the 1970s, psychiatrists and psychoanalysts could find "neurasthenia" in the American Psychiatric Association's list of psychiatric diagnosis, the Diagnostic and Statistical Manual of Mental Disorders, Second Edition (DSM-II). Under the section titled "Neuroses" are included the following nine conditions: Anxiety neurosis, Hysterical neurosis, Phobic neurosis, Obsessive compulsive neurosis, Depressive neurosis, Neurasthenic neurosis, Depersonalization neurosis, Hypochondriacal neurosis, and Other neurosis (DSM-II, 1968: 39-41). Not until 1980 did the APA formally drop neurasthenia from the DSM-III in the process of eradicating "neurosis," a term with strong 
JUNG Yeonsik : "Our one great national malady": Neurasthenia and American Imperial and Masculine Anxiety at the Turn of the Twentieth Century

psychoanalytic implications. ${ }^{p}$

Yet it was true that around 1920 neurasthenia lost its status as a fashionable diagnostic nomenclature of the age which expressed white male anxiety about the breakdown of familiar social, racial and sexual hierarchies, being replaced by other mental illnesses like neurosis, psychosis, and depression. Given the ideological significance of neurasthenia, the decline of the neurasthenic diagnosis should not be attributed solely to changes happening within the American medical profession. The fall of neurasthenia, like its rise, was also a cultural phenomenon, as renowned neurologist like Dana, while criticizing the limit of the neurasthenic diagnosis, was concerned with being "charged with dealing disrespectfully with our one great national malady" (Dana, 1904: 341). He was aware that the fall of neurasthenia signifies for some people that "American has been deleted of one of its most distinctive and precious pathological possessions" which worked as "an important stimulus to patriotism and racial solidarity" (Dana, 1904: 341). The paradoxical celebration of white neurasthenic men's weakness as a proof of their threatened privileged status, in a way, makes it possible to assume that neurasthenia lost its popularity because racial and masculine anxieties that gave rise to its symptoms were lessened as the United States acquired overseas colonies and established an empire at the turn of

9) DSM-III simply erased "Neurasthenia neurosis" from the list with a simple note, "This DSM-II category was rarely used" (DSM-III, 1980: 377). For the American Psychiatric Association's controversial efforts to revise and expand the list of mental disorders for their manual's third edition based on a neo-Kraepelinian neuropsychiatric approach, see Christopher Lane, Shyness: How Normal Behavior Became a Sickness (New Haven: Yale University Press, 2007), 39-103; Hannah S. Decker, The Making of DSM-III: A Diagnostic Manual's Conquest of American Psychiatry (Oxford: Oxford University Press, 2013). 
JUNG Yeonsik : "Our one great national malady": Neurasthenia and American Imperial and Masculine Anxiety at the Turn of the Twentieth Century

the twentieth century, in which American men could boost and solidify their racial and masculine identity. In this sense, the decline of a specific mental disorder called neurasthenia around 1920, I maintain, reflected the American ascendancy to global power in the early twentieth century, culminating in the U.S victory in the First World War.

America was built on the expansive imagination of people who kept dreaming about the lands of regeneration to the West, as Frederick Jackson Turner identified the frontier as the source of the "perennial rebirth" and "fluidity of American life" (Turner, 1920: 2). Yet, as discussed above, urbanization, industrialization, and mass influx of immigrants in the mid to late nineteenth century exhausted the remaining frontier, and according to the United States Census of 1890, the frontier no longer existed officially. Hence in his address "The Significance of the Frontier in American History" at the meeting of the American Historical Association in 1893, Turner declared the "end of the frontier" which, like John O'Sullivan's 1845 doctrine of Manifest Destiny, emphasized and legitimated the need for another frontier. Contemporary sociologist Adna F. Weber, debunking Turner's mythicized view of frontier, claimed in his 1899 report that American people's migration in the 1880s-90s was "cityward instead of westward" (Weber, 1889: 27). ${ }^{10)}$ For late

10) Not surprisingly, many new studies of the frontier myth questioned Frederick Jackson Turner's vision of the American frontier as pristine, unsettled wilderness, which was built on the binaries between wilderness and settlement, savagery and civilization as well as his willful blindness of the existence of Native Americans. See, among others, Jane T. Merritt. At the Crossroads: Indians and Europeans on a Mid-Atlantic Frontier (Chapel Hill: University of North Carolina Press, 2003); Richard White, The Middle Ground: Indians, Empires, and Republics in the Great Lakes Region, 16501815 (Cambridge: Cambridge University Press, 2011); Andrew Lipman. The Saltwater Frontier: Indians and the Contest for the American Coast (New Haven: Yale University Press, 2015). 
JUNG Yeonsik : "Our one great national malady": Neurasthenia and American Imperial and Masculine Anxiety at the Turn of the Twentieth Century

nineteenth-century American men who had already felt threatened from heterogeneous immigrants, the "end of the frontier" thesis was a shocking news that further inspired collective anxiety about the loss of a limitless fountain of American civilization

For American elites like Josiah Strong, the Protestant clergyman who popularized the idea of Anglo-Saxon supremacy, "American anxiety about the closed West" in this period "had global dimensions that express a fear of belatedness on the imperial stage" compared to the European powers (Kaplan, 1990: 668). Turner's "end of the frontier" thesis was an expression not only of ostensible American spatial anxiety but also of "parochial nationalism," through which American could see the expansion of imperial space as a solution to these widespread discontents (Van Alstyne, 1974: 101). Hence, claiming the primacy of national citizenship over state citizenship as proclaimed in the first section of the Fourteenth Amendment, late-nineteenth-century Republican administrations repudiated the Federalist ideal of a decentralized republic which limited the rights of national government and evoked a strong sense of national identity among contemporary Americans. ${ }^{11)}$ The Republican assertion of a more nationalistic Union opened what Bruce Ackerman calls "the Middle Republic," a regime defined by a government-led ideological shift into nationalism (Ackerman, 1991: 81-104).

11) The first section of the Fourteenth Amendment reads: "All persons born or naturalized in the United States, and subject to the jurisdiction thereof, are citizens of the United States and of the State wherein they reside." As a constitutional part of the Republicans' Reconstruction project enacted to protect the right of all citizens including ex-slaves against violation by their own state governments, particularly the former Confederate states, the Amendment of 1868 prefigures a new nationalistic foundation on which succeeding Republican administrations rested. 
JUNG Yeonsik : "Our one great national malady": Neurasthenia and American Imperial and Masculine Anxiety at the Turn of the Twentieth Century

Such an ideological redesign of the nation was part of "efforts to find substitutes for that former safeguard of democracy, the disappearing free lands"-that is, offshore colonies which made possible the American ascendancy to world power from the 1890s through the early twentieth century (Turner, 1920: 321). ${ }^{12)}$ It even allowed Americans to believe that they were "witnessing the simultaneous development of both democracy and empire" in the course of imperial expansion, no longer thinking of them as "antagonistic phenomena" (Giddings, 1900: 3). Indeed, in this period what Michael Hardt and Antonio Negri call "the second phase of U.S. Constitution," following Ackerman's constitutional periodization, Theodore Roosevelt's traditional imperialistic ideology and Woodrow Wilson's "internationalist ideology of peace as an expansion of the constitutional conception of network power" managed to re-found a nation into an empire (Hardt and Negri, 2000: 174).

The racial superiority of Anglo-Saxon Americans had been characterized by "the potency of their violent masculinity-their ability to outsavage the savage" in the frontier (Bederman, 1995: 181). Hence, the closure of the frontier in the west impelled late nineteenth-century white American expansionists to turn their attention overseas, the site for recuperating American masculinity. Given that the treatment for neurasthenic men was an escape to the frontier and wilderness, neurasthenia was a disease

12) For the ideological revamp of late nineteenth- and early twentieth-century United States and its relations with racism and the frontier issue, see, to name a few, Paul Frymer, Building an American Empire: The Era of Territorial and Political Expansion (Princeton, NJ: Princeton University Press, 2017), 263-81; Eric T. L. Love, Race over Empire: Racism \& U.S. Imperialism (Chapel Hill: University of North Carolina Press, 2004); Michael H. Hunt, The American Ascendancy: How the United States Gained and Wielded Global Dominance (Chapel Hill: University of North Carolina Press, 2007), 11-78. 
JUNG Yeonsik : "Our one great national malady": Neurasthenia and American Imperial and Masculine Anxiety at the Turn of the Twentieth Century

which also addressed late nineteenth-century American men's anxiety about the decline of the American pastoral ideal. Their uneasiness about barbarous and prolific "new" immigrants and unruly white women, in fact, was tied to this spatial anxiety which symptomatically signifies the crisis of American masculinity. By prescribing a retreat to wilderness for nervous men, the medical discourse of neurasthenia, in this sense, was urging American men to compete in the race for overseas territories.

Hence, U.S. imperial expansion of this period was figured as a national medical project; the Spanish-American War and America's acquisition of the overseas colonies of Hawai'i, Puerto Rico, Guam, and the Philippines in 1898 may have been an expression of turn-of-the-twentieth-century definitions of American masculinity (in crisis). Within this new frontier myth applied to the imperial project, "Asians become figurative Apaches and the Philippines become a symbolic equivalent of [Daniel] Boone's Kentucky or [Sam] Houston's Texas," in which American men rejuvenate their withered masculinity among the feminized natives (Slotkin, 1993: 53). The U.S. entry into the First World War, which led to the Allied victory in 1918 and then to a dramatic realignment of power away from any individual European country, had completed the recuperation of American manhood as well as America's ascendancy to a new world power. ${ }^{13)}$

13) For the recuperating effects of the First World War both on American masculinity and nationhood, see Glenda Sluga, "Masculinities, Nations, and the New World Order: Peacemaking and Nationality in Britain, France, and the United States after the First World War," Masculinities in Politics and War: Gendering Modern History. Eds. Stefan Dudink, Karen Hagemann, and John Tosh (Manchester: Manchester University Press, 2004), 238-54. 
JUNG Yeonsik : "Our one great national malady": Neurasthenia and American Imperial and Masculine Anxiety at the Turn of the Twentieth Century

If U.S. imperial expansion and global ascendancy was a potential cure for a diseased masculinity, it was also understood as "a necessary preventive measure that safeguarded and promoted the health and morals of Americans faced with disease threats across and within borders" (Jung, 2016: 195). More specifically, it was a form of medical warfare against the "foreign" bacteria of race/ethnicity-specific communicable diseases which, imported and spread by immigrants and foreigners, contaminated American bodies, souls, and soils. The strangers' supposed hereditary tendency to contract a certain disease, a belief founded on the confusion between contagious disease and hereditary disease, not only impugned the already despised populations, but also amplified the fear of racial degeneration. It provided momentum for the large-scale public health movement of the late nineteenth and early twentieth century, which, led by public-spirited physicians, sanitarians, engineers, nurses, and philanthropic groups who saw a moral and biological threat in crowded tenement houses, filthy streets, insufficient sewerage, and improper light, ventilation, and food, served to establish health departments and sanitary laws (Russell, 2012: 25-46). Such belief helped legitimate legal responses to racial biases, provoking the confluence of biological and juridical-political norms-that is, a biopolitical control through eugenics which intervened in the health and welfare of the population within the United States.

American eugenicists claimed that "it is a national duty," according to Charles B. Davenport," to regulate immigration" based on strict eugenic principles that block the entry of "idiots, imbeciles, feeble-minded persons, epileptics, insane person," and so on (Davenport, 1911: 220). Indeed the eugenic agenda that sought to preserve "purity" of American 
JUNG Yeonsik : "Our one great national malady": Neurasthenia and American Imperial and Masculine Anxiety at the Turn of the Twentieth Century

"blood" wielded an influence over the formulation of immigration policy, and various acts and bills by which the federal government claimed the power to regulate both the number of immigrants and their countries of origin were enacted in the 1890s-1920s. The fact that the number of immigrants rejected due to the "likelihood of becoming public charge"-a murky criteria based on eugenics and phrenology—was 4,458 in 1909, 8,182 in 1912, and 15,784 in 1914, accounting for 60-70 percent of all the causes of rejection, attests to the eugenic bases of severe restriction on immigration (King, 2002: 172).

By the 1920s, eugenicists also applied the measure of "negative" eugenics like sterilization to prevent the procreation of the alleged mentally and morally retarded immigrants in order to free future Americans from avoidable genetically transmitted disease (Kline, 2001: 61-94; Ordover, 2003: 125-158). Particularly, after the First World War which bequeathed an intelligence test-the I.Q. (intelligence quotient) which was developed in 1912 by a German psychologist William Stern-by which the U.S. Armed Forces tested more than 1.7 million male recruits, among which "the Negroes rank below Whites," eugenic arguments about racial hierarchy were further stimulated (Chase, 1977: 226-228; King, 2002: 169-170). Not surprisingly, an American psychologist-eugenicist Henry Herbert Goddard adopted the intelligence tests at Ellis Island to prove scientifically the inferiority of "new" immigrants like Jews, Hungarian, Russians, and southern Europeans, calling for the racist Americanization movement (Chase, 1977: 232-234). "Old stock" Americans' fear of the threatening forces, racially, morally, and pathologically, of "new" immigrants, in the end, enabled them to enact the National Origins Act, part of the Johnson-Reed Immigration Act, in 1924, which limited the 
JUNG Yeonsik : "Our one great national malady": Neurasthenia and American Imperial and Masculine Anxiety at the Turn of the Twentieth Century

number of immigrants to no more than 161,000 per year and allotted a quota to each European nation based on two percent of the number of people from that country listed in the 1890 U.S. census (instead of the 1910 or the 1920 census) in which immigrants from "old" western European countries predominated (Daniels, 1997: 133-143; King, 2002: 201-228). Restricting the influx of the allegedly unhygienic and retarded "new" immigrants, this act modified the composition of immigrants so that Americans no longer felt a threat to their racial and mental health. It in turn relieved Americans from the symptoms alleged to be associated with neurasthenia, or, more accurately, as suggested by Schuster, had them no longer diagnosing their nervousness as neurasthenia.

\section{Conclusion}

The neurasthenic body of an American man was a battleground where the turn-of-the-twentieth-century American medicine wielded its classifying power to justify a racial hierarchy favoring whites over others. It was also a battleground between the two sexes where American male physicians and neurologists utilized man's bodily weakness as a paradoxical proof of his sexual superiority over woman. The medical discourse of neurasthenia reflected late nineteenth- and early twentiethcentury white Anglo-Saxon men's belief in, as well as anxiety over, American values bolstered by their cultural, racial, and sexual superiority and consolidated through a conjunction of medicine and politics, and this explains why neurasthenia became popularized as America's most distinctive disease at the turn of the twentieth century despite its vague, boundless, and cumbersome nature. 
JUNG Yeonsik : "Our one great national malady": Neurasthenia and American Imperial and Masculine Anxiety at the Turn of the Twentieth Century

The neurasthenia diagnosis also addressed Americans' spatial anxiety derived from the sense of the loss of the frontier, as dramatized by the treatment for neurasthenic men. Channeled with the medical knowledge of neurology, it made American men's racial, sexual, and spatial anxieties function to act out their racist, nativist, misogynist, and imperialist impulses which legitimized exclusionary political techniques toward the racial and sexual others. Hence, the U.S. imperial expansion in the 1890s-1900s was reconfigured as a therapeutic journey for the recuperation of neurasthenic men's nerve forces and masculinity, and the eugenic-influenced immigration policy in the 1900s-1920s restricted and sterilized morally, physically, and mentally inferior immigrants and foreigners in the name of betterment and protection of the racial and mental health of Anglo-Saxon Americans.

Sustaining a political order rested on racial and sexual hierarchies both within and outside the American continent around 1920, American men believed that they were no longer liable to neurasthenia. It does not mean, of course, that they were no longer victims of anxiety and mental disorders. A series of nerve-wracking events in the 1910s-30s, such as the First World War, the Great Depression, and the women's suffrage movement, further made American men suffer from them. It means that the decline of neurasthenia was a cultural phenomenon which declared the dissolution of specific, time-tested psychological and somatic symptoms attached to this "one great national malady," which was more an ideological and cultural construct than a clinical entity that dramatizes U.S. racial, sexual, and imperial politics at the turn of the twentieth century. 
JUNG Yeonsik : "Our one great national malady": Neurasthenia and American Imperial and Masculine Anxiety at the Turn of the Twentieth Century

Keyword: decline of neurasthenia; American masculinity; imperialism; medical nativism; eugenics 
JUNG Yeonsik : "Our one great national malady": Neurasthenia and American Imperial and Masculine Anxiety at the Turn of the Twentieth Century

\section{REFERENCES}

$\langle$ Primary Sources >

Newspapers

The New Nation

The Western Druggist

American Psychiatric Association, Diagnostic and Statistical Manual of Mental Disorders, Second Edition (DSM-II) (Washington, DC: American Psychiatric Publishing, 1968).

, Diagnostic and Statistical Manual of Mental

Disorders, Third Edition (DSM-III) (Washington, DC: American Psychiatric Publishing, 1980).

Bassoe, Peter, "The Origin, Rise and Decline of the Neurasthenia Concept," Wisconsin Medical Journal 27 (1928), pp. 11-14.

Beard, George M., "Neurasthenia, or Nervous Exhaustion," Boston Medical and Surgical Journal 3 (1869), pp. 217-221.

A Practical Treatise on Nervous Exhaustion (Neurasthenia): Its

Symptoms, Nature, Sequences, and Treatment (New York: G. P. Putnam's Sons, 1880).

American Nervousness: Its Causes and Consequences, a Supplement

to Nervous Exhaustion (Neurasthenia) (New York: G. P. Putnam's Sons, 1881). Sexual Neurasthenia (Nervous Exhaustion): Its Hygiene, Causes,

Symptoms, and Treatment with a Chapter on Diet for the Nervous (New York:

E. B. Treat, 1884).

Beard, George M. and A. D. Rockwell, A Practical Treatise on the Medical and Surgical Uses of Electricity (New York: William Wood, 1868).

Carroll, Robert S., The Mastery of Nervousness Based Upon Self Reeducation (New York, MacMillan, 1917).

Dana, Charles L., "The Partial Passing of Neurasthenia," Boston Medical and Surgical Journal 150 (1904), pp. 339-344.

Davenport, Charles B., Heredity in Relation to Eugenics (New York: Henry Holt, 1911). 
JUNG Yeonsik : "Our one great national malady": Neurasthenia and American Imperial and Masculine Anxiety at the Turn of the Twentieth Century

Flexner, Abraham, Medical Education in the United States and Canada (New York: The Carnegie Foundation for the Advancement of Teaching, 1910).

Giddings, Franklin Henry, Democracy and Empire (New York: MacMillan, 1900).

Green, J. S., "Neurasthenia: Its Causes and Its Home Treatment," Boston Medical and Surgical Journal 109 (1883), pp. 75-78.

Jelliffe, Smith Ely, "Some Notes on Dispensary Work in Nervous and Mental Disease," The Journal of Nervous and Mental Disease 31-5 (1904), pp. 309-317.

Mitchell, S. Weir, Fat and Blood: An Essay on the Treatment of Certain Forms of Neurasthenia and Hysteria (Philadelphia: J. B. Lippincott, 1884).

Prince, Morton, "Hysterical Neurasthenia," Boston Medical and Surgical Journal 139 (1898), pp. 652-655.

Proust, Achille-Adrien and Gilbert Ballet, The Treatment of Neurasthenia. 1887. Trans., Peter Campbell Smith (London: Henry Kimpton, 1902).

Turner, Frederick Jackson, The Frontier in American History (New York: Henry Holt, 1920).

Van Deusen, Edwin. H., "Observations on a Form of Nervous Prostration, (Neurasthenia,) Culminating in Insanity," American Journal of Insanity 25 (1869), pp. 445-461.

Weber, Adna F., The Growth of Cities in the Nineteenth Century (New York: Columbia University Press, 1899).

Wright, Wade. "Industrial Hygiene," Mental Hygiene 5 (1921), pp. 497-498.

\section{〈Secondary Sources >}

Ackerman, Bruce, We the People: Foundations (Cambridge: Harvard University Press, 1991).

Bederman, Gail, Manliness \& Civilization: A Cultural History of Gender and Race in the United States, 1880-1917 (Chicago: University of Chicago Press, 1995).

Campbell, Brad, "The Making of 'American': Race and Nation in Neurasthenic Discourse," History of Psychiatry 18-2 (2007), pp. 157-178.

Caplan, Eric, Mind Games: American Culture and the Birth of Psychotherapy (Berkeley: University of California Press, 1998).

Carter, Julian B., The Heart of Whiteness: Normal Sexuality and Race in America, 1880-1940 (Durham: Duke UP, 2007). 
JUNG Yeonsik : "Our one great national malady": Neurasthenia and American Imperial and Masculine Anxiety at the Turn of the Twentieth Century

Chase, Allan, The Legacy of Malthus: The Social Costs of the New Scientific Racism (New York: Alfred A. Knopf, 1977).

Daniels, Roger, Not Like Us: Immigrants and Minorities in America, 1890-1924 (Chicago: Ivan R. Dee, 1997).

Foucault, Michel, The History of Sexuality, Volume 1: An Introduction. Trans., Robert Hurley (New York: Vintage, 1990).

Fuller, Robert C., Mesmerism and the American Cure of Souls (Philadelphia: University of Pennsylvania Press, 1982).

Gosling, F. G., Before Freud: Neurasthenia and the American Medical Community, 1870-1910 (Urbana and Chicago: University of Illinois Press, 1987).

Hardt, Michael and Antonio Negri, Empire (Cambridge: Harvard UP, 2000).

Higham, John, Strangers in the Land: Patterns of American Nativism 1860-1925 (New Brunswick, NJ: Rutgers University Press, 1955).

Hirshbein, Laura D., American Melancholy: Constructions of Depression in the Twentieth Century (New Brunswick, NJ: Rutgers University Press, 2009).

Haller, John S. and Robin M., The Physician and Sexuality in Victorian America (New York: Norton, 1977).

Humphreys, Margaret, "No Safe Place: Disease and Panic in American History," American Literary History 14-4 (2002), pp. 845-857.

Jung, Yeonsik, "The Immunity of Empire: Tropical Medicine, Medical Nativism, and Biopolitics in Sinclair Lewis's Arrowsmith," Literature and Medicine 34-1 (2016), pp. 185-206.

"A Medical Record of the Mulatto Hysteric: Racial and Sexual Politics in Gertrude Stein's 'Melanctha', English Studies 42-4 (2017), pp. 426-441.

Kaplan, Amy, "Romancing the Empire: The Embodiment of American Masculinity in the Popular Historical Novel of the 1890s," American Literary History 2-4 (1990), pp. 659-690.

King, Desmond, Making Americans: Immigration, Race, and the Origins of the Diverse Democracy (Cambridge, MA: Harvard University Press, 2002).

Kleinman, Arthur, Social Origins of Distress and Disease: Neurasthenia, Depression and Pain in Modern China (New Haven: Yale University Press, 1986).

Kline, Wendy, Building a Better Race: Gender, Sexuality, and Eugenics from the Turn of the Century to the Baby Boom (Berkeley: University of California Press, 
JUNG Yeonsik : "Our one great national malady": Neurasthenia and American Imperial and Masculine Anxiety at the Turn of the Twentieth Century

2001).

Kraut, Alan M., Silent Travelers: Germs, Genes, and the "Immigrant Menace" (Baltimore: John Hopkins University Press, 1994).

Kury, Patrick, "Neurasthenia and Managerial Disease in Germany and America: Transnational Ties and National Characteristics in the Field of Exhaustion 1880-1960," Sighard Neckel, Anna Katharina Schaffner, and Greta Wagner ed., Burnout, Fatigue, Exhaustion: An Interdisciplinary Perspective on a Modern Affliction (London: Palgrave Macmillan, 2017), pp. 51-73.

Lee, Sing, "Diagnosis Postponed: Shenjing Shuairuo and the Transformation of Psychiatry in Post-Mao China," Culture, Medicine and Psychiatry 23 (1999), pp. 349-380.

Lutz, Tom, "Varieties of Medical Experience: Doctors and Patients, Psyche and Soma in America," Marijke Gijswijt-Hofstra and Roy Porter ed., Cultures of Neurasthenia: From Beard to the First World War (Amsterdam: Rodopi, 2001), pp. 51-76.

Matthews, Jean V., The Rise of the New Woman: The Women's Movement in America, 1875-1930 (Chicago: Ivan R. Dee, 2003).

Micale, Mark S., Approaching Hysteria: Disease and Its Interpretation (Princeton: Princeton University Press, 1995).

Ordover, Nancy, American Eugenics: Race, Queer Anatomy, and the Science of Nationalism (Minneapolis: University of Minnesota Press, 2003).

Rosenberg, Charles E., No Other Gods: On Science and American Social Thought. Rev. ed., (Baltimore: Johns Hopkins University Press, 1997).

"The Place of George M. Beard in Nineteenth-Century Psychiatry," Bulletin of the History of Medicine 36 (1962), pp. 245-59.

Russell, Lopez, Building American Public Health: Urban Planning, Architecture, and the Quest for Better Health in the United States (New York: Palgrave Macmillan, 2012).

Schuster, David G., Neurasthenic Nation: America's Search for Health, Happiness, and Comfort, 1869-1920 (New Brunswick, NJ: Rutgers University Press, 2011).

Showalter, Elaine, Female Malady: Women, Madness, and English Culture, 1830-1980 (New York: Penguin, 1987). 
JUNG Yeonsik : "Our one great national malady": Neurasthenia and American Imperial and Masculine Anxiety at the Turn of the Twentieth Century

Sicherman, Barbara, "The Use of Diagnosis: Doctors, Patients, and Neurasthenia," Journal of the History of Medicine 32 (1977), pp. 33-54.

Slotkin, Richard, Gunfighter Nation: The Myth of the Frontier in Twentieth-Century America (New York: Harper, 1993).

Smith-Rosenberg, Carroll, Disorderly Conduct: Visions of Gender in Victorian American (New York: Oxford University Press, 1986).

Van Alstyne, Richard W., The Rising American Empire. 1960 (New York: Norton, 1974).

Wald, Priscilla, Contagious: Cultures, Carriers, and the Outbreak Narrative (Durham: Duke University Press, 2008).

Wang, Wen-Ji, "Neurasthenia, Psy Sciences and the 'Great Leap Forward' in Maoist China," History of Psychiatry 30-4 (2019), pp. 443-456.

Ware, Norma C. and Arthur Kleinman, "Culture and Somatic Experience: The Social Course of Illness in Neurasthenia and Chronic Fatigue Syndrome," Psychosomatic Medicine 54 (1992), pp. 546-560.

Wessely, Simon, "Old Wine in New Bottles: Neurasthenia and 'ME'," Psychological Medicine 20 (1990), pp. 35-53.

Wood, Ann Douglas, “'The Fashionable Diseases': Women's Complaints and Their Treatment in Nineteenth-Century America," The Journal of Interdisciplinary History 4-1 (1973), pp. 25-52. 


\section{"Our one great national malady": Neurasthenia and American Imperial and Masculine Anxiety at the Turn of the Twentieth Century}

JUNG Yeonsik*

White upper middle-class Americans at the turn of the twentieth century were entrenched in a battle with a newly discovered, or invented, mental illness called neurasthenia. This essay examines the ways in which the medical discourse of neurasthenia reflected late nineteenth- and early twentieth-century white Anglo-Saxon men's belief in, as well as anxiety over, American values bolstered by their idea of cultural, racial, and sexual superiority and consolidated through a conjunction of medicine and politics. The idea of neurasthenia as white American men's malady functioned as a mark both of whites' racial superiority to the "new" immigrants and African Americans as well as of women's intellectual inferiority to the opposite sex of their own race. Imposing a subtle distortion on the etiology and diagnosis of neurasthenia and associating it with specific groups of people, the "American disease" constituted

\footnotetext{
* Associate Professor, Department of English Language and Literature, Sungkyunkwan University / E-mail: apiaceres@skku. edu
}

Received: Apr. 28, 2021; Reviewed: Jul. 26, 2021; Accepted: Aug. 08, 2021 
JUNG Yeonsik : "Our one great national malady": Neurasthenia and American Imperial and Masculine Anxiety at the Turn of the Twentieth Century

the era's representative pathological symptoms which addressed AngloSaxon American men's anxieties about overcivilized effeminacy and racial and national decadence which was originated as a response to the racial and sexual heterogeneity.

This essay also argues that neurasthenia was an imagined disease which addressed late nineteenth-century American men's spatial anxiety about the decline of the American pastoral ideal caused by the closure of the frontier. Given that the treatment for neurasthenic men was an escape to the frontier in the West in which they could rejuvenate withered American masculinity, their uneasiness about barbarous, unhygienic, and prolific immigrants and unruly white women, in fact, was tied to their spatial anxiety which symptomatically signifies the crisis of American masculinity. Channeled through the medical knowledge of neurology, it made American men's racial, sexual, and spatial anxieties function to act out their racist, misogynist, nativist, and imperialist impulses which legitimized exclusionary political techniques toward the racial and sexual others such as the U.S. imperial expansion in the 1890s and 1900s and a eugenic-influenced immigration policy from the 1900s through the1920s.

In this sense, the decline of neurasthenia around 1920 should not be attributed solely to the continued efforts to professionalize American medicine accompanied by recent discoveries of chemical factors such as hormones and vitamins and the rise of psychiatry and psychology which offered physicians with a more specific theory of health built on clinical laboratory science. Like its rise, the decision to move away from the neurasthenic diagnosis was rather a cultural phenomenon, which reflected the American ascendancy to global power in the early twentieth century, particularly after the First World War. Sustaining a 
JUNG Yeonsik : "Our one great national malady": Neurasthenia and American Imperial and Masculine Anxiety at the Turn of the Twentieth Century

political order rested on racial and sexual hierarchies both within and outside the American continent, American men felt that they were no longer liable to specific, time-tested anxiety and somatic symptoms of neurasthenia, which was more an ideological and cultural construct than a clinical entity that dramatizes the racial, sexual, and imperial politics of the-turn-of-the-twentieth-century America.

Keyword: decline of neurasthenia; American masculinity; imperialism; medical nativism; eugenic 